\title{
EVALUASI STABILITAS FISIK DAN PROFIL DIFUSI SEDIAAN GEL (MINYAK ZAITUN)
}

\author{
A. Mumtihanah Mursyid \\ Fakultas Farmasi, Universitas Muslim Indonesia \\ mumtihanah.mursyid@umi.ac.id
}

\begin{abstract}
Olive oil contains vitamin $E$ which is a natural antioxidant that is effective to prevent premature aging. The aims of the research was to obtained the most stable gel formulation of polyfloral honey phamaceutically.

Physical stability evaluation carried out to in which the parameters were organoleptic, viscosity measurement, homogeneity, spreedability, $\mathrm{pH}$, and flowing type, at $5^{\circ} \mathrm{C}$ and $35^{\circ} \mathrm{C}$ for 12 hours on each temperature for 10 cycles.

Organoleptic assay showed that there was on change in color, odor, and concistency of all formula. Based on statistic analyses by Randomized design exhibited a significant change during storage. Homogeneity test showed that all formula posses even particle distribution. Spreedability test showed that all formula there were changes in viscosity. Based on rheogram exhibited thixotrophy-plastic flow type.

From physical evaluation obtained formula $B$ of gel was the must stable (Base gel of HEC). Based on release of active substances formula $B$ of gel (Base gel of HEC) showed the highest release of active substances.
\end{abstract}

Keywords: Virgin olive oil, Gel preparation, Antioxidant

\section{PENDAhUluan}

Minyak zaitun merupakan minyak tumbuhan yang bersifat emoolient. Minyak zaitun adalah antioksidant yang baik dan merupakan bahan moisturizing yang baik dalam kosmetik. Dalam uji coba pada hewan, penggunaan minyak zaitun secara topikal dapat melindungi kerusakan kulit akibat paparan sinar UVB (Khadijah, Z., 2008).

Menurut Surtiningsih (2005) minyak zaitun selain digunakan untuk berbagai masakan juga berkhasiat untuk perawatan kecantikan. Minyak zaitun kaya akan vitamin $\mathrm{E}$ yang merupakan anti penuaan dini. Minyak zaitun juga bermanfaat untuk menghaluskan dan melembabkan permukaan kulit tanpa menyumbat pori. Minyak zaitun merupakan pelembab yang baik untuk melembabkan kulit wajah dan tubuh. Selain itu, minyak zaitun bermanfaat untuk melepaskan lapisan sel-sel kulit mati.

Gel merupakan sistem semipadat terbuat dari partikel kecil atau molekul organik besar yang terpenetrasi melalui cairan (Gennaro, A. R., 1990). Beberapa dari sistem gel adalah transparan, yang secara estetika merupakan keadaan yang menyenangkan. Sistem yang lainnya adalah keruh, karena polimer berada dalam bentuk agregat koloid yang mendispersikan atau memantulkan cahaya. Kejernihan dari sistem gel yang keruh berkisar dari sedikit kabur (hazy) hingga whitish translucence (tembus cahaya yang berwarna keputihan) sama seperti yang diamati dengan gel petrolatum (Banker, G.S., 1995).
Gel mempunyai sifat yang menyejukkan, melembabkan, mudah penggunaannya, mudah berpenetrasi pada kulit sehingga memberikan efek yang menyembuhkan. Basis gel dapat dibedakan menjadi basis gel hidrofobik dan basis gel hidrofilik (Ansel,H,C., 2005). Pada penelitian ini digunakan basis gel hidrofilik karena daya sebar pada kulit baik, efeknya mendinginkan, tidak menyumbat pori-pori kulit, mudah dicuci dengan air, dan pelepasan obatnya baik $^{8}$. Karena itu, penelitian dilakukan untuk memformulasi minyak zaitun dalam beberapa jenis basis yang dievaluasi berdasarkan kestabilan secara farmaseutik dan diuji secaa difusi untuk melihat pelepasan minyak zaitun dari pembawa gel.

\section{METODE PENELITIAN}

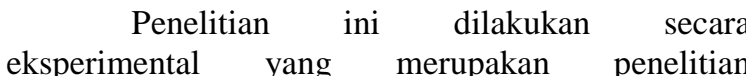
laboratorium dengan menggunakan Rancangan Acak Kelompok (RAK). Zat aktif diformulasi dengan variasi basis Karbopol, Hydroxylethyl celulosa (HEC), dan Tragakan, kemudian dilakukan pengujian sifat farmaseutik dan pelepasan bahan aktifnya. Formula lengkap dapat dilihat pada tabel 1.

Evaluasi secara farmaseutik dilakukan beebrapa pengujian untuk melihat kestabilan formula. Di antaranya:

\section{A. Evaluasi kestabilan dengan kondisi dipaksakan \\ Untuk menguji kestabilan dari produk yang} diformulasi biasanya dilakukan dengan metode kondisi dipaksakan (stress condition) untuk 
mempercepat peruraian dan mengurangi waktu yang diperlukan untuk pengujian. Sediaan gel diuji kestabilannya pada suhu $5^{\circ} \mathrm{C}-35^{\circ} \mathrm{C}$ selama 10 siklus dimana tiap 1 siklus adalah 12 jam.

Tabel 1. Rancangan Formula Gel Minyak Zaitun Dengan Variasi Dasar Gel

\begin{tabular}{ccccc}
\hline \multirow{2}{*}{ No } & \multirow{2}{*}{ Bahan } & \multicolumn{3}{c}{ Konsentrasi (\% b/b) } \\
\cline { 2 - 5 } & Madu Polifloral & 20 & Formula B & Formula C \\
\hline 1. & Carbopol $^{\circledR} 940$ & 1 & 20 & 20 \\
2. & Tragakan & - & 3 & - \\
3. & HEC (Hydroxyethyl cellulose $)$ & - & - & - \\
4. & Trietanolamin & 0,8 & - & 7,2 \\
5. & Propilen glikol & 10 & 10 & - \\
6. & Metil Paraben & 0,18 & 0,18 & 0,17 \\
7. & Propil paraben & 0,02 & - & 0,03 \\
8. & Aquadest & & Add 100 & \\
9. & & & & \\
\hline
\end{tabular}

\section{B. Evaluasi dengan beberapa parameter kestabilan fisika}

Evaluasi kestabilan fisika dari s ediaan gel dilakukan dengan beberapa parameter fisika yaitu pengukuran viskositas, pengujian organoleptis, penentuan nilai yield, penentuan tipe aliran, pengukuran $\mathrm{pH}$, daya sebar, dan homogenitas.

1) Pengujian organoleptis sediaan gel

Pengujian organoleptis meliputi pemeriksaan perubahan bau, warna, dan konsistensi dari formula sebelum dan sesudah kondisi dipaksakan.

2) Pengukuran viskositas sediaan gel

Sebanyak 50,0 $\mathrm{mL}$ sediaan gel dimasukkan kedalam gelas ukur 50,0 mL kemudian diukur viskositasnya dengan menggunakan Viskometer Brookfield RVT yang dilengkapi dengan spindle no.7 dengan kecepatan $50 \mathrm{rpm}$ (putaran per menit) kemudian dicatat hasilnya. Evaluasi dilakukan terhadap sediaan gel sebelum dan sesudah kondisi dipaksakan.

3) Penentuan aliran

Untuk penentuan tipe aliran, dilakukan pengukuran viskositas gel pada berbagai kecepatan yaitu $(5,10,20$, 50, dan $100 \mathrm{rpm})$. Kemudian diukur nilai yieldnya dengan menggunakan Viskometer Brookfield RVT spindle no.7. Kemudian dicatat hasilnya. Evaluasi dilakukan terhadap sediaan gel sebelum dan sesudah kondisi dipaksakan.

4) Pengujian Homogenitas

Pengujian dilakukan dengan mengoleskan sediaan gel pada obyek gelas, kemudian ditutup dengan deck glass. Lalu diamati dengan mikroskop perbesaran $40 \times 10$.
5) Pemeriksaan daya sebar

Sediaan sebanyak 200,0 mg diletakkan diatas kaca bening berdiameter $20 \mathrm{~cm}$, ditutup dengan kaca bulat bening berdiameter $20 \mathrm{~cm}$, tebal $2 \mathrm{~mm}$, dan berat 147,42 g. Diatasnya diberi beban sebesar 125 g, $225 \mathrm{~g}$, dan $325 \mathrm{~g}$. Kemudian diukur diameter daya sebarnya.

6) Pengukuran $\mathrm{pH}$

Sediaan sebanyak 25,0 mL dimasukkan ke dalam gelas kimia $100 \mathrm{~mL}$, diukur $\mathrm{pH}$ dari sediaan dengan $\mathrm{pH}$ meter. Pengukuran dilakukan terhadap setiap formula sebelum dan sesudah kondisi dipaksakan.

Evaluasi pelepasan bahan aktif melalui pengujian difusi menggunakan kertas Whatman no.1 yang diimpregnasi pada cairan spangler. Komposisi cairan spangler : Asam palmitat $10 \mathrm{~g}$, Asam oleat 15 g, Asam stearate $5 \mathrm{~g}$, Minyak kelapa $15 \mathrm{~g}$, Parafin 10 g, Kolesterol $5 \mathrm{~g}$, Lilin putih $15 \mathrm{~g}$, semua bahan dilebur dalam cawan petri. Setelah itu kertas Whatman dicelupkan atau direndam dalam caian spangler selama 15 menit. Kemudian diangkat dan dikeringkan dengan kertas tissue lalu ditentukan jumlah cairan yang terserap. Diambil 1 gram gel, diratakan di kertas mermbran.

Cuplikan diambil dari cairan reseptor dalam gelas kimia sebanysk $5 \mathrm{ml}$. Setiap pengambilan selalu diganti dengan cairan hydroalcoholic sebanyak $5 \mathrm{ml}$. pengambilan cuplikan dilakukan pada menit ke 5, 10, $15,25,35,45,60,80,100,160$ dan 180 menit kemudian diukur serapannya pada panjang gelombang maksimum.

Untuk menganalisis data dalam penelitian ini menggunakan teknik analisis statistik inferensial karena penelitian ini untuk menguji hipotesis dan analisis inferensial yang digunakan berdasarkan desain Rancangan Acak Kelompok (RAK). 
III. HASIL DAN PEMBAHASAN

\section{A. Hasil Penelitian}

Pengujian organoleptis setelah formulasi hampir memiliki kesamaan bau, warna dan konsistensi sediaan. Pada setiap formula aik itu A, B dan C memiliki bau khas, warna orange kecoklatan dan konsistensi yang kental.

Hasil pengukuran daya sebar untuk setiap formula, pada table 2 .

Tabel 2. Hasil pengukuran daya sebar gel minyak zaitun

\begin{tabular}{ccccc}
\hline \multirow{2}{*}{ Formula } & & Beban & \multicolumn{2}{c}{ Sediaan Gel (cm) } \\
\cline { 3 - 5 } & & $(\mathbf{g})$ & Sebelum & Sesudah \\
\cline { 3 - 5 } A & & 125 & 3,9 & 4,0 \\
& & 225 & 4,3 & 4,3 \\
& 325 & 4,6 & 4,4 \\
& Total & & 12,8 & 12,7 \\
& & 125 & 3,5 & 3,5 \\
B & & 225 & 3,9 & 3,9 \\
& & 325 & 4,0 & 3,9 \\
& \multirow{2}{*}{ Total } & & 11,4 & 11,3 \\
& & 125 & 3,8 & 4,2 \\
C & & 225 & 5,3 & 4,5 \\
& & 325 & 5,4 & 11,8 \\
\hline
\end{tabular}

Keterangan :

Formula A : Gel dengan basis Karbopol

Formula B : Gel dengan basis HEC (Hydroxyethyl Celulosa)

Formula $\mathrm{C}$ : Gel dengan basis Tragakan

Beberapa pengujian yaitu pengukuran $\mathrm{pH}$, viskositas dan nilai yield yang telah dilakukan pada setiap formulasi sebelum dan sesudah keadaan dipercepat dapat dilihat pada Tabel 3. Sedangkan untuk pengujian aliran untuk setiap formulasi gel sebelum dan setelah kondisi dipercepat pada berbagai

rpm dengan menggunakan Viskometer Brookfield RVT dengan spindel No.7 dapat dilihat pada Tabel 4. Pengujian-pengujian ini merupakan evaluasi farmaseutika dari setiap formulasi gel. Untuk uji pelepasan bahan aktif dari basis gel dapat dilihat pada Tabel 5.

Tabel 3. Hasil pengukuran $\mathrm{pH}$, viskositas dan nilai yield gel minyak zaitun

\begin{tabular}{ccccc}
\hline Pengukuran & Kondisi & Formula A & Formula B & Formula C \\
\hline \multirow{2}{*}{ pH } & Sebelum & 5,25 & 5,31 & 5,73 \\
& Sesudah & 5,34 & 5,91 & 5,56 \\
\multirow{2}{*}{ Viskositas } & Sebelum & $933,33 \pm 0,01$ & $217,33 \pm 1,2$ & $252 \pm 0,01$ \\
& Sesudah & $157,33 \pm 0,5$ & $182,66 \pm 0,9$ & $157,33 \pm 1,13$ \\
\multirow{2}{*}{ Nilai Yield } & Sebelum & $54,44 \pm 0,09$ & $83,56 \pm 2,3$ & $70,78 \pm 0,01$ \\
& Sesudah & $43,75 \pm 0,8$ & $68,73 \pm 0,07$ & $40,45 \pm 0,5$ \\
\hline
\end{tabular}


Tabel 4. Hasil pengukuran aliran pada berbagai rpm dengan menggunakan Viskometer Brookfield RVT dengan spindel No.7

\begin{tabular}{ccccc}
\hline \multirow{2}{*}{ Kondisi } & RPM & \multicolumn{3}{c}{ ALIRAN } \\
\cline { 2 - 4 } & 5 & Formula A & Formula B & Formula C \\
\hline \multirow{3}{*}{ Sebelum } & $586 \pm 0,01$ & $800 \pm 1,13$ & $693,33 \pm 0,9$ \\
& 20 & $320 \pm 0,4$ & $580 \pm 0,05$ & $526 \pm 0,6$ \\
& 50 & $186 \pm 1,6$ & $386,66 \pm 0,07$ & $386,66 \pm 0,04$ \\
& 100 & $94,67 \pm 0,9$ & $216 \pm 0,9$ & $241,33 \pm 1,3$ \\
& 5 & $42 \pm 0,1$ & $130 \pm 0,071$ & $159,33 \pm 0,05$ \\
\hline \multirow{3}{*}{ Sesudah } & 10 & $280 \pm 0,09$ & $473,33 \pm 0,13$ & $400 \pm 0,09$ \\
& 20 & $160 \pm 0,01$ & $326,67 \pm 0,11$ & $233,33 \pm 0,31$ \\
& 50 & $77,33 \pm 1,5$ & $181,33 \pm 0,03$ & $154,67 \pm 0,5$ \\
& 100 & $44,66 \pm 2,12$ & $111,33 \pm 0,17$ & $105,33 \pm 0,02$ \\
\hline
\end{tabular}

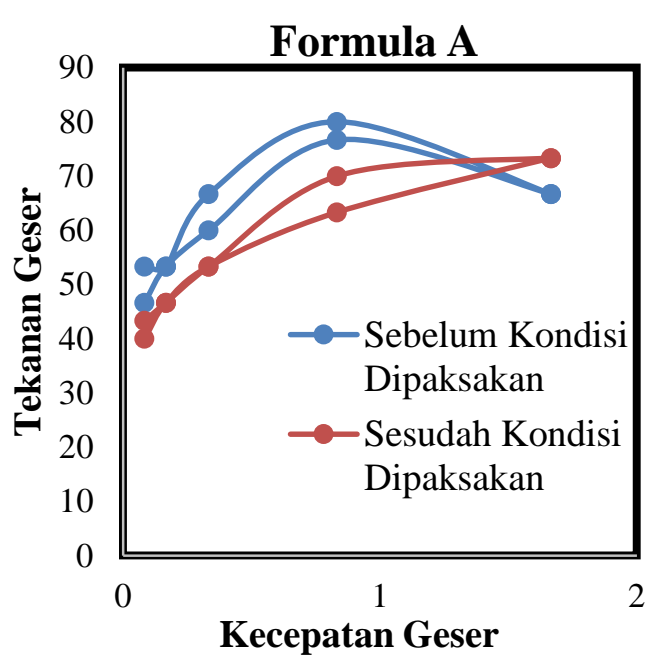

Gambar 1. Rheogram Gel Minyak zaitun dengan Basis Karbopol Sebelum dan Sesudah Kondisi Dipaksakan.

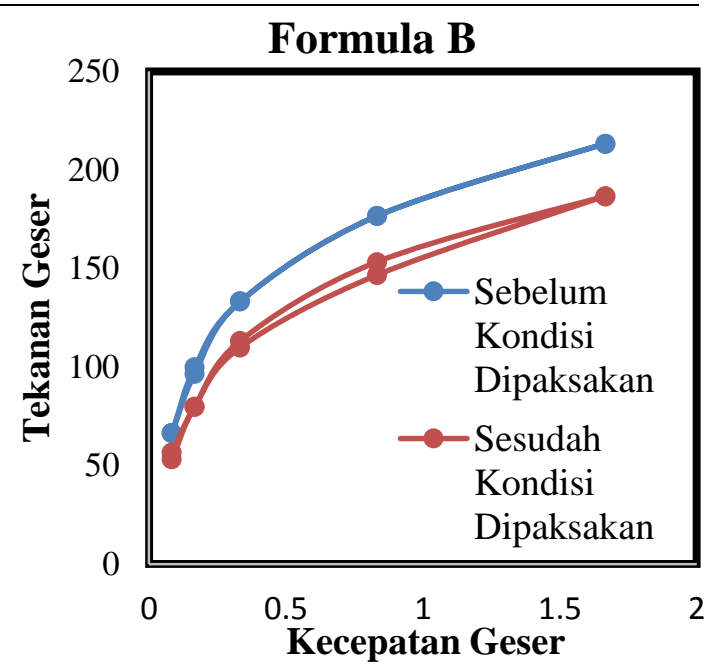

Gambar 2. Rheogram Gel Minyak zaitun dengan Basis Hydroxyethyl Celulosa (HEC)

Sebelum

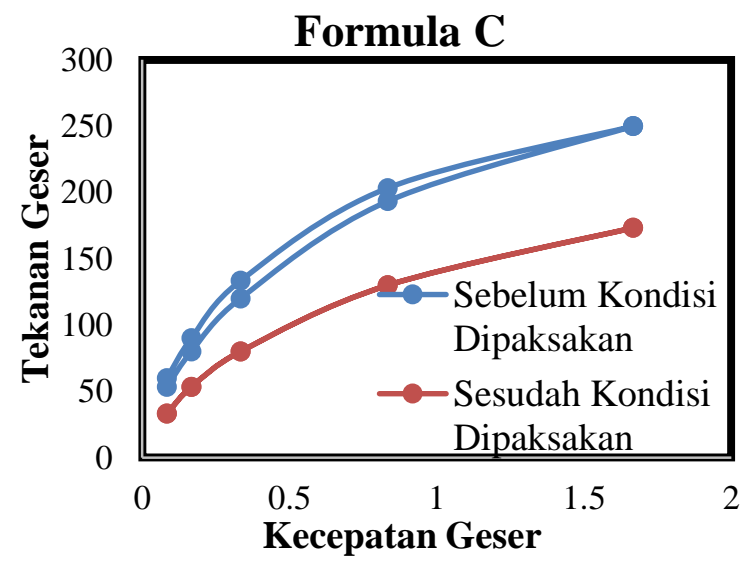

Gambar 3. Rheogram Gel Minyak zaitun dengan

Basis Tragakan Sebelum dan Sesudah Kondisi

Dipaksakan. 
Tabel 5. Hasil uji difusi formulasi gel minyak zaitun

\begin{tabular}{cccccc}
\hline \multirow{2}{*}{ Formula } & \multicolumn{5}{c}{ Kadar (ppm) Minyak Zaitun } \\
& \multicolumn{5}{c}{ Menit ke } \\
\cline { 2 - 6 } & $\mathbf{1 5}$ & $\mathbf{4 5}$ & $\mathbf{8 0}$ & $\mathbf{1 6 0}$ & $\mathbf{1 8 0}$ \\
\hline $\mathrm{A}$ & 0,59 & 1,53 & 2,11 & 1,74 & 1,48 \\
$\mathrm{~B}$ & 0,58 & 1,34 & 1,93 & 1,09 & 1,04 \\
$\mathrm{C}$ & 0,57 & 1,54 & 2,02 & 1,22 & 0,76 \\
\hline
\end{tabular}

\section{B. Pembahasan}

Pada penelitian ini masing-masing sediaan dibuat dalam tiga bahan dasar gel yang berbeda meliputi bahan yang bersumber dari basis tragakan (gom alam), HEC (semisintetik) dan karbopol (sintetik) yang dalam formulasinya dimana karbopol akan membentuk gel melalui disperse yang seragam dalam medium kemudian dinetralkan dengan alkali kuat. Salah-satu alkali yang digunakan yaitu TEA (Trietanolamin) yang berfungsi untuk menetralkan karbopol yang bersifat asam melalui mekanisme yakni pembentukan garam (reaksi netralisasi) yang mengakibatkan gugus karboksil melarut sehingga terbentuk gel. Selain itu, trietanolamin juga berfungsi untuk melindungi karbpol yang memiliki sifat mudah terdegradasi oleh panas yang menyebabkan penurunan viskositas gel (Krell, 1996).

Menurut penelitian Khadijah (2008), dalam uji coba pada hewan, penggunaan minyak zaitun secara topikal dapat melindungi kerusakan kulit akibat paparan sinar UVB. Untuk itu yang ingin dilihat adalah adanya pengaruh bahan dasar gel dalam penetrasi zat aktif dalam hal ini minyak zaitun dalam formulasi gel pelindung kulit dari sinar UVB dan memberikan efek antioksidant yang selanjutnya pengujian berdasarkan enam parameter diantaranya pemeriksaan organoleptis, pengukuran viskositas, penentuan tipe aliran, homogenitas, daya sebar, pengukuran $\mathrm{pH}$, dan penetuan bobot jenis dan kerapatan dari minyak zaitun serta pengujian pelpasan zat aktif yaitu minyak zaitun dari pembawa gel. Pengujian kestabilan dilakukan dengan metode kondisi dipaksakan (stress condition) dengan penyimpanan pada suhu $5{ }^{\circ} \mathrm{C}$ dan $35{ }^{\circ} \mathrm{C}$ selama 10 siklus, masing-masing siklus berdurasi 12 jam. Tujuan dilakukannya kondisi dipaksakan adalah untuk mengevaluasi sediaan dan untuk mempersingkat waktu pengujian. Pemeriksaan organoleptis dilakukan untuk mengetahui ada tidaknya pengaruh penyimpanan pada warna, bau dan konsistensi sediaan. Adapun hasil pengamatan yang diperoleh dari ketiga formula gel minyak zaitun sebelum dan sesudah kondisi dipaksakan tidak mengalami perubahan dari segi warna, bau dan konsistensi.

Pada pengukuran viskositas data yang diperoleh, dilakukan analisa secara statistik dengan menggunakan metode rancangan acak kelompok (RAK). Hasil analisis menunjukkan bahwa viskositas dari semua formula baik formula A, formula B dan formula $\mathrm{C}$ mengalami perubahan yang sangat signifikan pada kondisi sebelum dan sesudah kondisi dipaksakan. Hal ini menunjukan bahwa adanya kondisi dipaksakan sangat mempengaruhi viskositas semua formula. Kemudian dilakukan uji lanjutan menggunakan JNTD (Jarak Nyata Terdekat Duncan) karena nilai koefisien keseragaman diantara diatas $10 \%$ yaitu $21,038 \%$.

Pada uji lanjutan JNTD diperoleh hasil yaitu berdasarkan perbandingan antar kondisi sebelum dan sesudah kondisi dipaksakan menunjukkan formula A dengan basis karbopol dan formula B dengan basis HEC (Hydroxyethyl celulosa) mengalami perubahan yang tidak signifikan baik pada kondisi sebelum dan sesudah kondisi dipaksakan sedangkan pada formula $\mathrm{C}$ dengan basis tragakan mengalami perubahan yang signifikan. Hal ini menunjukkan bahwa adanya kondisi penyimpanan mempengaruhi viskositas formula $\mathrm{C}$, namun tidak mempengaruhi viskositas formula A dan formula B. Kemungkinan hal ini disebabkan karena adanya pengaruh polimer terhadap perubahan suhu. Dimana ketika suatu gel disimpan pada suhu panas maka bentuk rantai polimer akan melepaskan gulungan yang berbetuk bola (disentangle) mengakibatkan viskositas gel menurun (encer). Sedangkan bila suatu gel disimpan pada suhu dingin maka rantai polimer akan memendek dan akan saling bergabung dan lama kelamaan gel akan mengkisut (entangle) sehingga terjadi perubahan viskositas setelah kondisi dipaksakan

Parameter selanjutnya yang dilakukan pada pengujian kestabilan adalah penentuan tipe aliran pada sediaan gel minyak zaitun. Tipe aliran dapat dilihat dari rheogram serta nilai yield sediaan. Nilai yield adalah harga yang harus dipenuhi agar sediaan dapat mengalir. Adanya nilai yield disebabkan oleh kontak antara partikel-partikel yang berdekatan, yang harus dipecah sebelum sediaan dapat mengalir. Terdapat beberapa faktor yang dapat mempengaruhi terbentuknya aliran dari sediaan semipadat yaitu kompetisi antar pelepasan ikatan sekitar makromolekul terlarut atau pemecahan gaya Vander Waals di sekitar partikel-partikel terdispersi oleh shear dan pembentukan beberapa ikatan kembali oleh Brown. Keseimbangan antara pemecahan dan pembentukan ikatan akan bergeser lebih ke arah pemecahan untuk meningkatkan shear. Pengurangan ikatan rantai atau ikatan antar partikel menghasilkan suatu aliran yang lebih kecil dan menunjukkan viskositas yang rendah (Gennaro, et al,.1990).

Nilai yield diperoleh dari pengukuran viskositas sediaan pada beberapa rpm, kemudian dari data yang diperoleh dapat ditentukan tekanan geser 
(shearing stress) dan kecepatan geser (rate of share), maka diperoleh sifat aliran non newton yaitu untuk formula gel dengan basis karbopol, HEC, dan Tragakan memiliki aliran thiksotropik-plastis (Gambar 1-3). Dikatakan memiliki aliran thiksotropik karena aliran menaik dan menurunnya tidak berimpitan sehingga terbentuk hysteresis loup (adanya celah yang terbentuk diantara kurva menaik dan menurun). Semakin luas celah (hysteresis loup) yang terbentuk maka suatu sediaan semakin tidak stabil karena suatu sediaan dikatakan stabil ketika tidak ada celah yang terbentuk antara kurva menaik dan kurva menurun. Sedangkan aliran plastis ditunjukkan dengan adanya nilai yield, yang ditandai dengan adanya kurva yang tidak memotong titik $(0,0)$, tetapi memotong sumbu shearing stress pada nilai yield.

Untuk pengujian homogenitas, ini dilakukan untuk melihat distribusi partikel dari sediaan gel. Hasil yang diperoleh menunjukkan bahwa sediaan gel sebelum dan sesudah kondisi dipaksakan memiliki partikel yang terdistribusi secara merata.

Untuk pengujian daya sebar, pengujian ini dilakukan untuk melihat kemampuan mengalir atau keluarnya gel dari tube. Daya sebar sangat dipegaruhi oleh viskositas sehingga semakin tinggi viskositas maka diameter daya sebar sediaan akan semakin kecil. Pengukuran diameter daya sebar sediaan gel dilakukan menggunakan plat kaca dengan diameter 20 $\mathrm{cm}$. Hasil menunjukkan bahwa formula A, formula B, dan formula $\mathrm{C}$ pada kondisi sebelum dan sesudah kondisi dipaksakan terjadi penurunan viskositas yang dilihat dengan adanya penurunan rata-rata diameter daya sebar (Tabel 2). Kemungkinan hal ini disebabkan karena adanya pengaruh polimer terhadap perubahan suhu. Dimana ketika suatu gel disimpan pada suhu panas maka bentuk rantai polimer akan melepaskan gulungan yang berbetuk bola (disentangle) mengakibatkan viskositas gel menurun (encer). Sedangkan bila suatu gel disimpan pada suhu dingin maka rantai polimer akan memendek dan akan saling bergabung dan lama kelamaan gel akan mengkisut (entangle) sehingga terjadi perubahan viskositas setelah kondisi dipaksakan.

Pengukuran $\mathrm{pH}$ sediaan gel dilakukan untuk mengetahui apakah $\mathrm{pH}$ sediaan gel tersebut sesuai dengan $\mathrm{pH}$ kulit. Dari hasil pengukuran $\mathrm{pH}$ menunjukkan bahwa ketiga formula gel memiliki $\mathrm{pH}$ yang berada pada rentang $\mathrm{pH}$ balance $(5,25--5,91)$.

Dari hasil analisis terhadap kestabilan sediaan gel mnyak zaitun sebelum dan sesudah kondisi dipaksakan, yang paling stabil secara farmasetik adalah formula B. Hal ini karena formula B dengan penggunaan basis HEC (Hydroxyethyl celulosa), menunjukkan perubahan yang tidak signifikan baik kondisi sebelum dan sesudah kondisi dipaksakan.

Pengujian selanjutnya dilakukan uji difusi yang bertujuan untuk mengetahui laju pelepasan suatu bahan aktif dari pembawanya dan juga untuk melihat seberapa besar kadar bahan aktif yang dapat berpenetrasi melalu membran secara in-vitro. Pada uji difusi ini dilakukan selama 3 jam, dengan pengambilan cuplikan sebanayk $5 \mathrm{ml}$ setiap beberapa menit sekali, setelah itu diukur dalam spektrofotometer UV-Vis. Pengukuran dilakukan pada panjang gelombang $253 \mathrm{~nm}$, diperoleh berdasarkan hasil scanning panjang gelombang maksimum minyak zaitun.

Pada formula A, B dan C kadar minyak zaitun pada menit ke-15 setelah itu kadarnya turun pada menit ke-100. Berdasarkan hasil uji difusi dari seluruh formula gel, dapat dianalisa bahwa formula B memiliki laju peleasan yang lebih baik, ditandai dengan jumlah kadar bahan aktif yang lebih besar yang berpentrasi melalui membrane ke dalam cairn reseptor dibandingkan dengan kedua formula yang lain. Faktor-faktor yang mempengaruhi laju penetrasi dari suatu bahan aktif ke dalam kulit adalah : kosentrasi bahan aktif terlarut $(C)$ karena laju penetrasi sebanding dengan konsentrasi, koefesien partisi $(K)$ antara kulit dan pembawa, serta koefesien difusi yang menggambarkan tahanan pergerakan molekul obat melalui barrier pembawa $\left(D_{v}\right)$ dan pembatas kulit $\left(D_{s}\right)$ (Martin, A., 1993).

\section{KESIMPULAN}

Dari hasil penelitian dapat disimpulkan bahwa minyak zaitun dapat dibuat sediaan gel yang baik dan stabil dengan menggunakan basis HEC (Hydroxyethyl celulosa). Karena dari hasil evaluasi stabilitas fisik dan profil disolusi menunjukkan stabilitas fisik yang baik dan laju pelepasan bahan aktif yang paling tinggi.

\section{DAFTAR PUSTAKA}

Ansel,H,C. 2005. Pengantar Bentuk Sediaan Farmasi edisi IV. Jakarta : UI Press.

Banker, G. S. 1995. Modern Pharmaceutics. USA : Marcel Dekker.

Gennaro,A.R. 1990. Remington's Pharmaceutical Sciences $18^{\text {th }}$ edition.Pensylvania : Mack Publishing company.

Khadijah, Z. 2008. Khasiat Dahsyat Minyak Zaitun. Yogyakarta : Gapura Publishing.

Krell. 1996. Value-added product from Beekeeping. Food and Agricultur Organization of the United Nations.

Martin, A. 1993. Physical Pharmacy: Physical Chemical Principles in The Pharmaceutical 
Science. $3^{\text {rd }}$ ed. Philadelphi London: Lea \& Febiger.

Surtinigsih. 2005. Cantik Dengan Bahan Alami. Jakarta : PT Elex Media Komputindo.

Voigt, R. 1995. Buku Pelajaran Teknologi Farmasi.

Yogyakarta : Gadjah Mada University Press. 